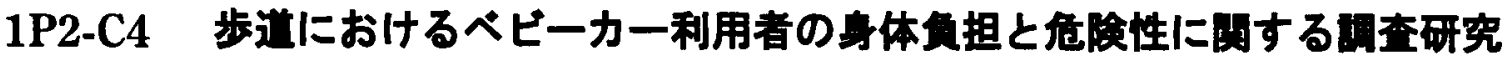

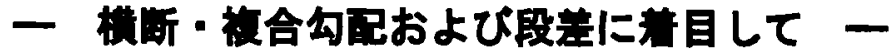

\section{Investigation of Physical Strain and Danger in Sidewalk in Stroller Users}

- Focusing on Cross and Compound Slope and Level Difference -

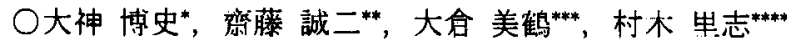

$*, * *$ 儿州大学大学院芸術上学拊, $* * *$ 横浜市立大学垁学部者绕学科 ****九州大学大学院芸術工学研究院

*Hirofumi Ogami, **Seiji Saito, Graduate School of Design, Kyushu University ***Mitsuru Okura, Department of Nursing, Yokohama City University ****Satoshi Muraki, Faculty of Design, Kyushu University

\section{I 、はじめに}

都市部の歩道には，横断・複合勾配となる車両乗り入れ部 や段差が設けられることが多く，べビーカー利用者には大き な負担と予期せぬ事故の原因になり得ると考えられる。そこ で本研究では，歩道上の横断・複合勾配部および段差が，心゙ ビーカー利用者の身体負担や事故の危険性に及ぼす影響を明 らかにすることを目的とした。

\section{II. 酮查方法}

調查期間：2005年5月26日〜2005年9月8日

\section{1. 歩道計測調查}

福岡市南区・博多区・中央区の歩道30力所を対象として，車 両乗り入れ部での横断勾配（幅員方向 $1 \mathrm{~m}$ 毎）ほか主な寸法や 勾配の值を，メジャーとデジタル角度計（新潟精機製, DP-90） を用いて計测した。

\section{2. ベビーカー利用者へのアンケート調查}

歩道計測調查で得られた寸法や勾配の値を参照して，幅2 mで一般的な形状の歩道 (Fig. 1)を再現した模型 (1/22スケー ル）を作成した.これを用いて福岡市内の公園・公共施設等で, ベビーカーを利用している保護者を対象として，a. 横断・複 合勾配を含む歩道での歩行経路，b.歩道各部における主観的 身体負担と危険感，c. 歩道における事故や危険な状況の経験， についてアンケート調查を行った，有効回答数は，58名（男

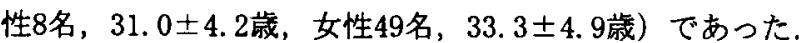

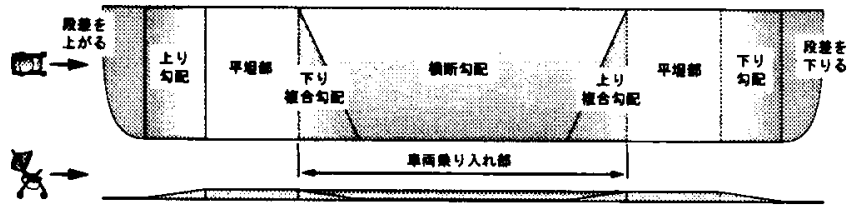

Fig.1 Sidewalk containing cross and compound slope

III. ベビーカー利用者へのアンケート明查結果

1. 段差と横断·複合勾配を含む歩道での歩行経路

段差（商さ $2 \mathrm{~cm}$ ，国土交通省の定めるガイドライン）を上が る状況においては，全体の $85 \%$ がベビーカーの前輪を持ち上 げて通過すると回答し，高い割合を示した．また，車両乗り 入れ部などの横断・複合勾配部を含む步道におけるべビーカ 一利用者の步行経路は, 直進・円弧状（車道側・民地側）の3 グループに大きく分類し，平均值で示した (Fig. 2)，歩道の中 央ではなく勾配の緩やかな民地側を通行する傾向や，勾配の 影響を受けて車道側に大きく進路が流されるケースがあるこ とを確認できた。

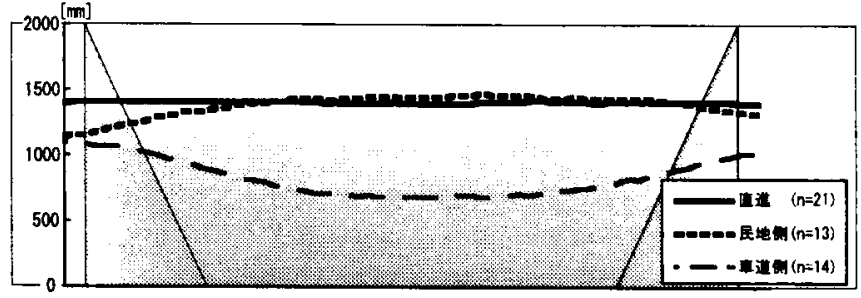

Fig.2 Walking route in cross and compound slope

2. 歩道各部における主観的身体負担と危险感（Fig. 3）

平坦部と比較すると，全ての部分において身体負担・危険 感ともに平坦部よりも有意に大きかった $(p<0.001)$ ，身体負担 は，「段差を上がる」が最も大きな做を示し，次いで「上り複合 勾配」、「上り勾配」、「横断勾配」が上位に挙がった。危険感も 「段差を上がる」が最も大きかったが，「段差を下りる」、「横断・ 複合勾配の上り下り」が上位となったことが特徽であった。

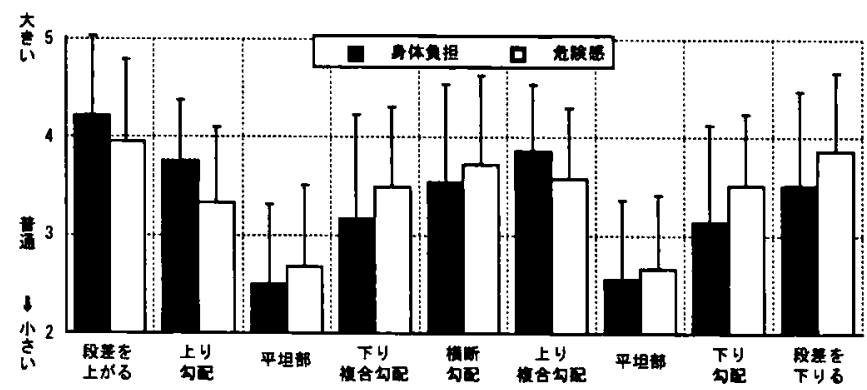

Fig.3 Physical strain and danger in each part of sidewalk

3. 歩道における事故や危険な状況の経験

歩道におけるべビーカー使用時の事故経験では，段差に車 輪が取られての転倒や，複合幻配部での車道側への傾きが主 に挙げられただけでなく，買い物後などでベビーカーに荷物 を多く積んだ状況が特に危険だという意見も多数得られた。

\section{IV. 考察}

身体負担は上りや横方向の勾配，段差の通行時に增し，危 険感はべビーカーが前方や左右に傾く状況で増す傾向がある と考えられる．段差では前輪を上げる場合が多いことや，横 断・複合勾配部では車道側に進路が大きく流される場面もあ ることからも，段差や横断・複合勾配部でベビーカーの進路や 歩行速度を思うように保てない状況に，乳幼児保護者は負担 や危険性を感じていることが推測される.

以上の結果を踏まえると，歩道における横断勾配や複合公 配，段差がベビーカー利用者の身体負担や危険感を增加させ る大きな要因であると考えられる：今後は客観的指標も用い てこれらバリアの身体負担や危険性を定量的に評価し，より 快適で安全な歩道形態の提案に活かしていきたい。 